\title{
ANALYTICAL CAPABILITIES OF MODERN INFORMATION SYSTEMS AS PART OF THE INCOME-BASED BUSINESS VALUATION METHOD
}

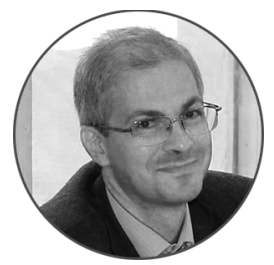

Article history: Received 30 October 2017 Received in revised form 1 December 2017 Accepted 4 December 2017 Translated 6 March 2018 Available online 27 March 2018

JEL classification: G32

Keywords: income-based method, discounting, cash flow, discount rate, information system

\section{Semen Yu. BOGATYREV}

Financial University under Government of Russian Federation, Moscow, Russian Federation sbogatyrev@fa.ru

\begin{abstract}
Importance The research focuses on new software and information tools for valuation. The research deals with aspects of business valuation based on the income-based valuation method.

Objectives I scrutinize aspects of adjusting the valuation framework to new analytical capabilities and demonstrate distinctive scope of information and analytical data on ratios and metrics stored in such systems and available for financial analysts.

Methods The research is based on the DCF method from perspectives of income-based business valuation.

Results I analyze capabilities of software and technological tools of modern information systems and measure the value of different items using the DCF method through various models. The article displays positive aspects of analytical tools of the information systems and identifies what restrictions and limits they impose on a financial analyst. The article unveils the limited nature of data resources in foreign information systems and indicates the Russian alternative information resources for improving the use of the DCF-based models.

Conclusions and Relevance Financial analysts may benefit from new capabilities of model information systems. They streamline primary data collection and processing for business valuation purposes and standardization of financial reporting. The article outlines the future of new information resources and their use in business valuation. The findings may prove useful in financial analysis and financial reporting.
\end{abstract}

(c) Publishing house FINANCE and CREDIT, 2017

The editor-in-charge of this article was Irina M. Vechkanova

Authorized translation by Irina M. Vechkanova

\section{Introduction}

The article examines how information technologies, business valuation methods can be used by financial analysts. The materials are intended to help financial analysts use new capabilities of information systems effectively. For purposes of effective value analysis, I unfold specific details of analytical and information

${ }^{\dagger}$ For the source article, please refer to: Богатырев С.Ю. Аналитические возможности современных информационных систем при реализации методов доходного подхода к оценке стоимости бизнеса. Финансовая аналитика: проблемы и решения. 2018. T. 11. № 1. С. 43-61.

URL: https://doi.org/10.24891/fa.11.1.43 capabilities of modern information systems, such as Bloomberg, Thomson Reuters, Russia's Prime, etc.

\section{The Use of Forecasting Capabilities of Information Systems as part of the DCF Model}

Free Cash Flow to Equity and Free Cash Flow to the Firm are assessed on the basis of financial statements. Forecast estimates to be embedded into the valuation model are made through data extrapolation.

In international literature on valuation, authors overview different materials that may produce statutory 
indicators to be integrated into assessments of cash flows [1].

Value analysts may be perplexed with a more complicated algorithm for predicting future figures. Appraisers point out situations when specialized assets and conventional profit-making trading businesses are measured [2]. Specialized editions on valuation keep on arguing about the applicability of valuation standards to different types of appraisals [3].

It would be the simplest way to assume that the gained momentum of cash flow growth will remain in the future. The relationship between cash flow and its determining factors is incidentally believed to survive. Modern methods for financial reporting standardization, identification and substantiation of value factors are strongly linked with mathematical models based on real figures [4].

The income-based valuation framework can be configured in line with complex models arising from more advanced mathematical methods, such as options [5-7]. Complex models and methods of valuation are developed with neural networks as well [8, 9]. Such studies indeed are more popular in case of small and family business [10].

It is noteworthy that scientific literature presents studies juxtaposing and complementing income-based and cost approaches [11]. It streamlines the reciprocal development of synthetic valuation methods. For example, valuation based on the residual value $[12,13]$.

The first step in cash flow forecasting is to analyze the uploaded information on the company as showed in Fig. 1.

Brief Description of Careffour SA. This company is interesting for valuation purposes. The company is a blue chip in the French stock market. There is a lot of value analytics on the company. It is examined by leading fundamental analysts and included into many investors' portfolios. Here I view it from perspectives of available analytical and other information.

For purposes of income-based valuation, Carrefour SA is an exemplary case of applying such methods. It demonstrates a growth in its revenue and intends to increment its profit even more. In a way, it resembles the Russian retail company Magnit starring the Russian stock market in 2015.

Free cash flow of Carrefour SA may be insufficient to extrapolate cash flows since there was a gap in 2013. Extrapolation methods are quite well developed as accountants master this area very well as part of financial reporting under International Financial Reporting Standards [14].

Let us have a look at Dollar Tree, Inc. from the USA. Fig. 2 depicts its profile in the Thompson Reuters database.

I deliberately choose this company as it illustrates the U.S. stock market. Dollar Tree, Inc. has good performance results in stock trading and fundamental indicators underlying its value.

After the data are uploaded, I can get the table with metrics to be used in valuation.

The simplest method to project cash flows is to assess components in the given proportion against sales volume of the company [15]. As for Free Cash Flow to the Firm, financial leverage is considered to remain unchanged. This simplified approach implies that new investment in fixed assets is made in the same proportion of depreciation charges. For example, this idea is voiced by authors of the multi-step cash-flow prediction model [16].

If the analyst presumes depreciation should reflect annual costs to be incurred to keep the existing capacity, the difference between fixed capital investment and depreciation equals additional contributions to the capital stock. The difference depends on an increase in the company's capacity. The components below are needed to make respective assessments:

- projected increase in sales;

- estimates of After Tax Net Operating Profit is for Free Cash Flow for the Firm (FFCF) or profit margin for Free Cash Flow to Equity (FCFE);

- proportion of additional fixed capital investment (incremental FCInv) and increase in sales volume (output);

- ratio of working capital investment (WCInv) and increase in sales volume (output); 
- estimation of financial leverage (debt ratio, DR).

As for margin, it is worth mentioning different mentality in approaching relative figures. A Russian accountant, say, treats relative values, such as markup, against the base, that is cost. In this respect, the accountant is in agreement with a procurement manager. The metric is an effective tool for financial analysis and managerial efforts. Margin is a tool employed by the Western economists, being an unrelated analytical metric gauged as the percentage of cost and markup (as one or another type of profit). It is convenient to compare a number of companies, trace dynamics, measure proportions and ratios, which would be easy to use in calculations.

This shall be kept in mind when handling traditional foreign analytical ratios. This is not about good or bad, but rather just about models of thinking.

It is the way for assessing the ratio of capital expenditures net of depreciation expenses to an increase in sales, and the ratio of different sales volumes (increase in working capital, increase in sales).

Certain ratios are projected for the forecast period when future cash flows are predicted.

Indicators of Dollar Tree, Inc. are precisely forecast in accordance with the recent financial statements uploaded from the Thompson Reuters database.

Let us examine the financial statements of Dollar Tree and make relevant calculations using signed-off financial statements starting from 2015. The calculations are based on Income Statements and Cash Flow Statements. Processed data are presented in Table 1.

The company's revenue grew by 25.7 percent in 2015 year-on-year.

The return on an increase in fixed and working capital is assessed in the table.

I calculate FCFF, that is the cash flow to the entire invested capital, provided that a 25.7 percent increase perseveres.

EBIT margin is sourced from the special section of the menu - Estimates.
I calculate auxiliary metrics: EBIT margin - 12\%, increase in sales volume - USD 2,211 million.

Table 2 provides my calculations of cash flow in the forecast period in line with the existing ratios and growth trend.

Such relatively scarce cash flow stems from considerable investment in fixed and working capital. The final figure will grow if an increase in sales projected by Thompson Reuters is taken into account.

A separate point of the menu is intended for forecasting an increase in sales volume (Fig. 3). I open it and get the value of sales volume for the selected period (Fig 4). It is also possible to choose the average value in the table, which was previously suggested as an optional forecast for three years to come.

EBIT margin remains unchanged. However, the absolute increase will be lower: EBIT margin - 12\%, increase in sales volume - USD 1,789 million.

Therefore, FCFF will be calculated as shown in Table 3.

As seen in the calculation, FCFF rose substantially, though an increase in revenue is forecast to be 5 percent less. So, it proves the importance of being prudent in forecasting.

The similar scheme based on net investment in fixed and working capital can be used to calculate FCFE but net profit will be an initial component in this case.

Referring to Dollar Tree, Inc., which traders and fundamental analytics tend to, DLTR.O stock ticker acquires source data for calculations likewise.

Net profit is measured through net profit margin, i.e. the ratio of net profit and revenue.

It is not only net profit that differentiates the calculation. What makes it different is that it involves net borrowings. Net borrowings are measured on the basis of the target ratio of equity and borrowings.

Source data for the calculation are as follows. Sales volume is USD $10,390.57$ million, net profit margin is $4.85 \%$, increase in sales is USD 1,789 million (Table 4).

Please note that all leading information systems employ their own valuation models. They more often than not 
use the dividend discount model (for example, Bloomberg and Thompson Reuters). The valuation model is also fitted with an analytical forecast module, which depicts an estimated increase in earnings per share as needed for the model.

The valuation option is activated in the menu of the company profile (Fig. 5).

Fig. 6 reflects how it works in case of Dollar Tree, Inc. in the Thompson Reuters database.

Estimates are given in three formats intended for users, analysts (StarMine affiliated with Thompson Reuters) and industry-specific purposes, review (Fig. 7).

\section{Value Analysis by the One-Stage Discounted Cash Flow Valuation Model}

After I figure out the cash flow, I apply it to business valuation.

First of all, I shall mention that the DCF models are extremely sensitive to input data. Even if an estimated increase in revenue changes by 5 percent, cash flow demonstrates serious modifications. If the discount rate is added, the final result will fluctuate even more.

Hence value analysts usually rely upon the scenario-based approach to analyze business valuation results and subsequently make their judgments.

The one stage model for equity valuation through the DCF method is expressed as follows:

$$
V_{0}=F C F E_{0}(1+g) /(r-g) \text {, }
$$

where $F C F E_{0}$ stands for free cash flow to equity;

$g$ is the rate of cash flow growth;

$r$ is the discount rate on equity.

Let us measure the equity through a common stock of Petroleo Brasileiro. Scholars majoring in valuation pay great attention to the way the discount rate is set up in post-crisis circumstances. Most analyzable cases relate to situations when a smaller entity needs to be appraised [17].

Assessing the discount rate, it shall not be overlooked that the discount rate and assumptions shall be determined identically, notwithstanding the income-based approach or comparative approach is used [18].

The Factsheet report provide principal points needed to examine the financial and economic profile of the company. This report is generated in the Thompson Reuters database, being prepared in three colors, i.e. red, orange and blue.

It is worth mentioning the behavioral toolkit used to visualize some behavioral strategies with colors. Behavioral factors are considered to form the discount rate [19].

Table 5 provides source data to be used in the one stage model through the DCF method and constant increase in profit.

Under the CAPM model, the discount rate is $23 \%$. Therefore, the market value of the share is BRL 77.31, with the current quotation amounting to BRL 14 per share.

The surprising result may be explained with the Price to Earnings ratio (P/E ratio). While the average $\mathrm{P} / \mathrm{E}$ ratio is 23 in the sector, it is 9 for Petroleo Brasileiro. The behavioral analysis technique is likely to be appropriate in this case.

I conduct the scenario-based analysis to delve into the issue. Table 6 comprises different metrics for further assessment of the share price.

Under favorable circumstances, the value increases up to BRL 90.59 per share. Unfavorable conditions do not cause dramatical changes in the value.

\section{Two-Stage Discounted Cash Flow Valuation Model}

There are models of free cash flow to the firm (FCFF) and free cash flow to equity (FCFE).

The model features two stages of an increase in cash flow. At the first stage (estimation), cash flow changes year-on-year, while being fixed during the second stage.

Valuation formulas are as follows:

- in case of cash flow to the firm (FCFF):

$$
\begin{aligned}
& \text { Business Value }=\sum_{(t=1)}^{n} F_{C F F_{t}} /(1+W A C C)^{t}+ \\
& +F C F F_{n+1} /(W A C C-g) \cdot 1 /(1+W A C C)^{n} ;
\end{aligned}
$$


- in case of free cash flow to equity (FCFE):

$$
\begin{aligned}
& \text { Equity Value }=\sum_{(t=1)}^{n} F C F E_{t} /(1+r)^{t}+ \\
& +F C F E_{n+1} /(r-g) \cdot 1 /(1+r)^{n} .
\end{aligned}
$$

Terminal value, or the value in the post-forecast period, can be measured using the P/E ratio. In this case, the estimated profit is used.

It is very important for this model to measure the terminal value since it accounts for a significant portion of the total value. In its simplest expression, the rate of cash flow increase is the same at each of the two stages.

For analytical purposes, please refer to Hyundai Steel South Korea. The company details are stored in the Thompson Reuters database. A more detailed profile is uploaded as a pdf-file.

I determine source metrics for valuation purposes They'd better be taken from the Estimates menu in the relevant section of the system. For convenience purposes, the system can visualize figures as graphs. You may not be subscribed to such leading databases as Thompson Reuters or Bloomberg. Issuers' financial statements can be found on websites of financial companies.

I upload the data as a table and start the valuation process using them. Sales per share, net profit margin and increase in sales are measured on the basis of the available report. Investment in fixed and working capital is specified in the Cash Flow Statement.

Table 7 displays the way input data to be uploaded into the two-stage DCF model are measured by processing source reporting data of the company.

Equity risk premium, ERP, is applied to gauge the discount rate on equity. It is available in Thompson Reuters and Bloomberg databases. The calculation algorithm is conventional as set forth in literature on valuation [20].

As for South Korea, this command generates a graphical result in the Thompson Reuters database. Uploading it into an Excel file, I get a convenient body of data. The beta coefficient of the company is assessed by applying the respective command within the system. Table 8 and 9 present the assessment of the discount rate and value respectively.

In the forecast period, the share value is KRW 25,840.71. Table 10 shows the value measurement in the postforecast period.
The share value at the designated time (present value) is KRW 36,519.73. The sum of values totals KRW 62,360.44. It results from the StarMine's model (Thompson Reuters database).

As the forecast reveals, StarMine Agency assigns much higher value to one share on the basis of the market value, which significantly exceeds the current quotation.

Analytical models are generally closed, being kept as know-how by agencies and advisers. Hence, it is often problematic to understand the logic of analysts' actions unless they provides relevant clarifications in an addendum to the computational part.

\section{Conclusion}

Although the income-based approach and respective methods have been expected to become less popular for a long time, they still remain the most frequent option for valuation and value analysis. The above material explains the reasoning behind it.

First, modern information systems allow for quick and proper assessment of all components underlying the computational framework of the income-based approach. They are easy to handle and configure.

Second, predictive capabilities of the income-based valuation methods rise substantially after various techniques of sectoral specialists, financial analysts are combined in a single information pool used for valuation purposes.

Third, trying to attract clients, developers of information systems designed perfect valuation modules, calculators for quick value measurements, which are evident to rest upon the income-based valuation method. The calculators have precision settings, with their results being close to the market value of listed stocks. They persuade the clients trading in the stock market to opt for valuation.

Fourth, rich information tools streamline and facilitate the convergence of the income-based and comparative approaches, ongoing exchange of analytical findings and sharing of calculations.

Upon the onset of popular information systems, income-based valuation has reached a new development level. Financial analysts and appraisers should actively master this tool for conducting effective value analysis and valuation. 


\section{Table 1}

Assessment of metrics

\begin{tabular}{|c|c|c|c|}
\hline Metric & 2013 & 2014 & 2015 \\
\hline Increase in revenue, $\%$ & - & - & 25.7 \\
\hline EBIT margin for three years, $\%$ & - & - & 12.43 \\
\hline Effective income tax rate, average for three years & - & - & 35.85 \\
\hline Fixed capital investment, c.u. & 312.2 & 331.2 & 325.6 \\
\hline Depreciation charges, c.u. & 175.3 & 190.5 & 205.9 \\
\hline Incremental fixed capital, c.u. & 136.9 & 140.7 & 119.7 \\
\hline Increase in sales, c.u. & - & 445 & 762 \\
\hline Percentage of net investment in revenue increase & - & 31.62 & 15.71 \\
\hline Increase in working capital, c.u. & - & - & 97.2 \\
\hline Percentage of increased working capital in revenue increase & - & - & 12.76 \\
\hline
\end{tabular}

Source:Authoring

\section{Table 2}

Assessment of cash flow in the forecast period, million USD

\begin{tabular}{ll}
\hline Metric & Value \\
\hline Sales volume & $10,812.85$ \\
\hline Earnings before interest and tax (EBIT) & $1,297.54$ \\
\hline Earnings before interests and tax (EBIT) with tax adjustments (tax rate) & 832.39 \\
\hline Incremental fixed capital & -523.16 \\
\hline Incremental working capital & -282.01 \\
\hline FCFF & 27.21 \\
\hline
\end{tabular}

Source:Authoring

\section{Table 3}

Assessment of cash flow in the forecast period, according to forecasts by Thompson Reuters, million USD

\begin{tabular}{ll}
\hline Metric & Value \\
\hline Sales volume & $10,390.57$ \\
\hline Earnings before interest and tax (EBIT) & $1,246.87$ \\
\hline Earnings before interests and tax (EBIT) with tax adjustments (tax rate) & 799.88 \\
\hline Incremental fixed capital & -423.24 \\
\hline Incremental working capital & -228.15 \\
\hline FCFF & 148.49 \\
\hline
\end{tabular}

Source:Authoring 


\section{Table 4}

Free Cash Flow to Equity from incremental fixed capital, million USD

\begin{tabular}{ll}
\hline Metric & Value \\
\hline Net Income & 503.94 \\
\hline Incremental fixed capital & -423.24 \\
\hline Incremental working capital & -228.15 \\
\hline Net borrowings - increase in non-current accounts payable & 252.49 \\
\hline FCFE & 105.04 \\
\hline
\end{tabular}

Source:Authoring

\section{Table 5}

Input data for the one-stage DCF model with a constant increment in profit

\begin{tabular}{ll}
\hline Metric & Value \\
\hline FCFE, BRL per share & 11 \\
\hline Rate of cash flow growth, \% & 8 \\
\hline Risk-free rate, $\%$ & 10.23 \\
\hline Equity risk premium, \% & 6.08 \\
\hline Beta coefficient of the company & 2.16 \\
\hline
\end{tabular}

Source:Authoring

\section{Table 6}

Scenario-based analysis of changed in value

\begin{tabular}{lll}
\hline Metric & High value & Low value \\
\hline FCFE, BRL per share & 11 & 11 \\
\hline Rate of cash flow growth, $\%$ & 10 & 5 \\
\hline Risk-free rate, $\%$ & 10.75 & 9.5 \\
\hline Equity-risk premium, $\%$ & 6.5 & 5.5 \\
\hline Beta coefficient of the company & 2.5 & 1.5 \\
\hline Discount rate, R CAPM, $\%$ & 27 & 18 \\
\hline Market value of equity per share & 71.18 & 90.59 \\
\hline
\end{tabular}

Source:Authoring

\section{Table 7}

Input data to be uploaded into the two-stage DCF model

\begin{tabular}{ll}
\hline Metric & Value \\
\hline Current sales volume, billion KRW & 16,133 \\
\hline Shares issued & $131,270,000$ \\
\hline Current sales volume per share, KRW & $122,899.37$ \\
\hline Increase in sales in the forecast period, \% & 12.82 \\
\hline Increase in sales in the post-forecast period, \% & 6.34 \\
\hline Net profit margin, \% & 5.83 \\
\hline Incremental fixed capital, \% of an increase in revenue & 25 \\
\hline Incremental working capital, \% of an increase in revenue & 17 \\
\hline
\end{tabular}

Source:Authoring

Please cite this article as: Bogatyrev S.Yu. Analytical Capabilities of Modern Information Systems as Part of the Income-Based Business Valuation Method. Digest Finance, 2018, vol. 23, iss. 1, pp. 41-54. 


\section{Table 8}

Assessment of the discount rate through the CAPM model, \%

\begin{tabular}{ll}
\hline Metric & Value \\
\hline Risk-free rate & 4.53 \\
\hline Market premium & 8.16 \\
\hline Beta coefficient & 1.85 \\
\hline R CAPM & 19.63 \\
\hline
\end{tabular}

Source:Authoring

\section{Figure 1}

\section{Upload of the company information (screenshot)}

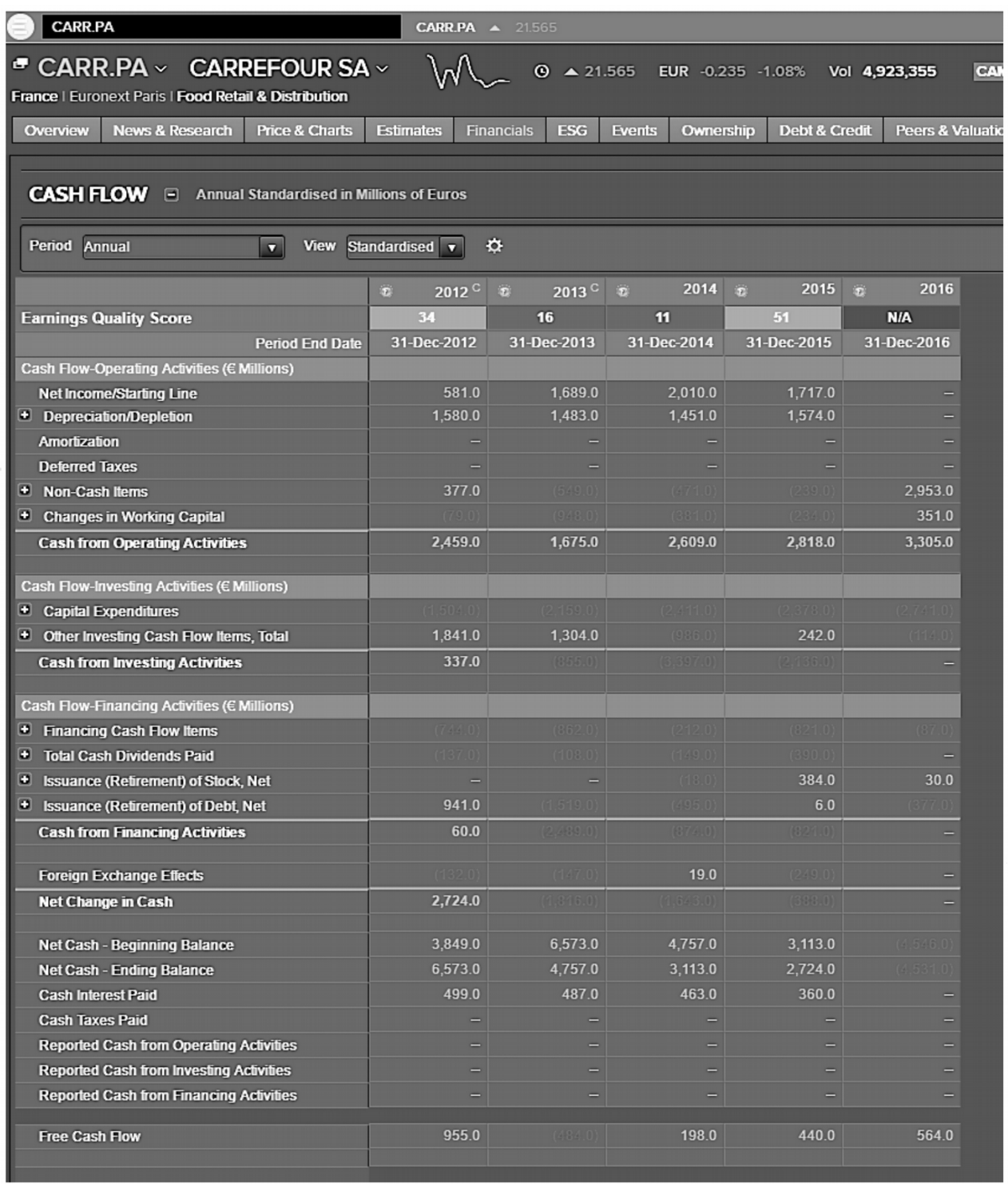

Source:Thomson Reuters Information system 


\section{Figure 2}

Dollar Tree, Inc. data in Thomson Reuters Information system (screenshot)

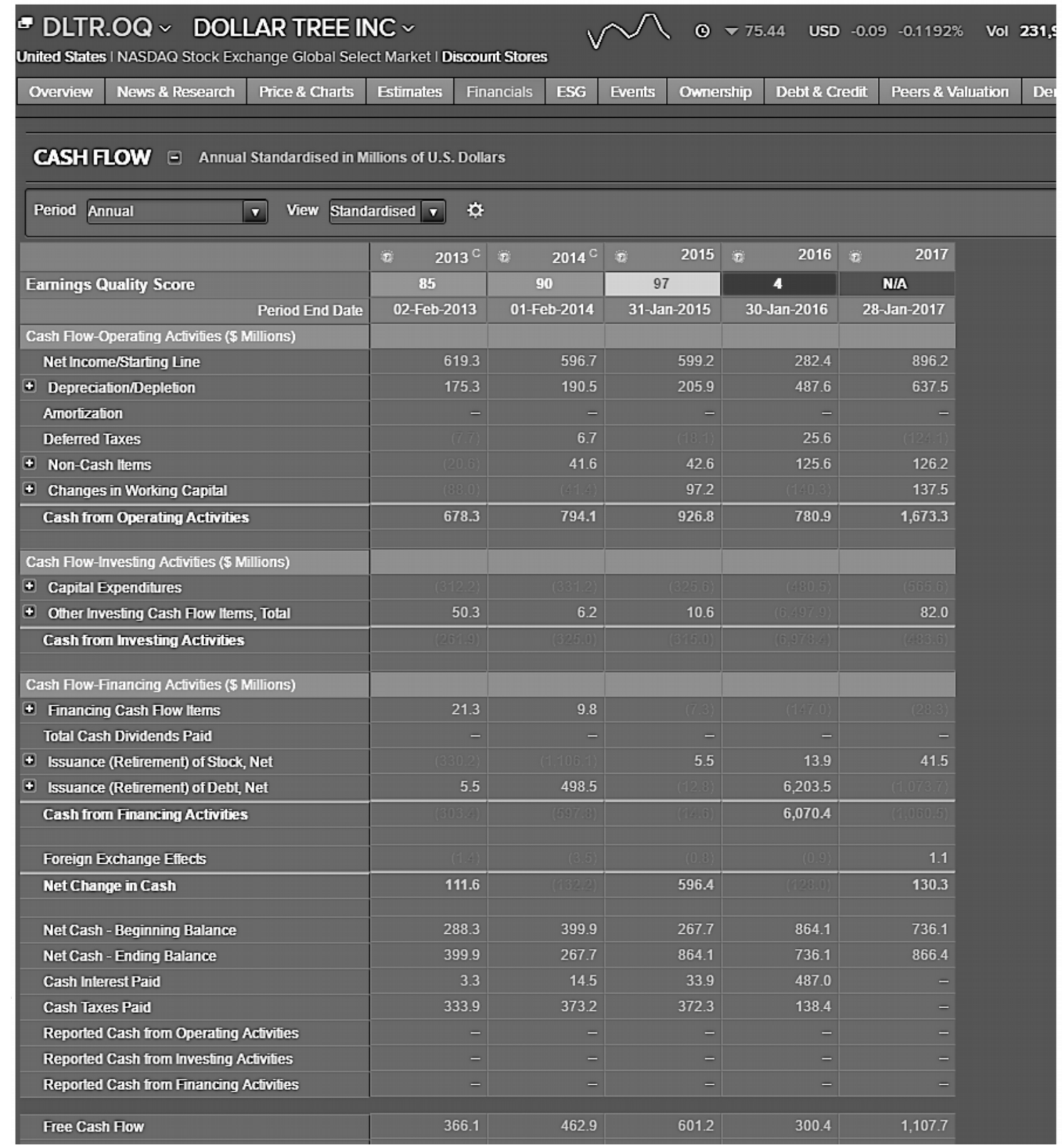

Source:Thomson Reuters Information system

Please cite this article as: Bogatyrev S.Yu. Analytical Capabilities of Modern Information Systems as Part of the Income-Based Business Valuation Method. Digest Finance, 2018, vol. 23, iss. 1, pp. 41-54.

https://doi.org/10.24891/df.23.1.41 


\section{Figure 3}

The sales growth forecast in Thomson Reuters Information system (screenshot)

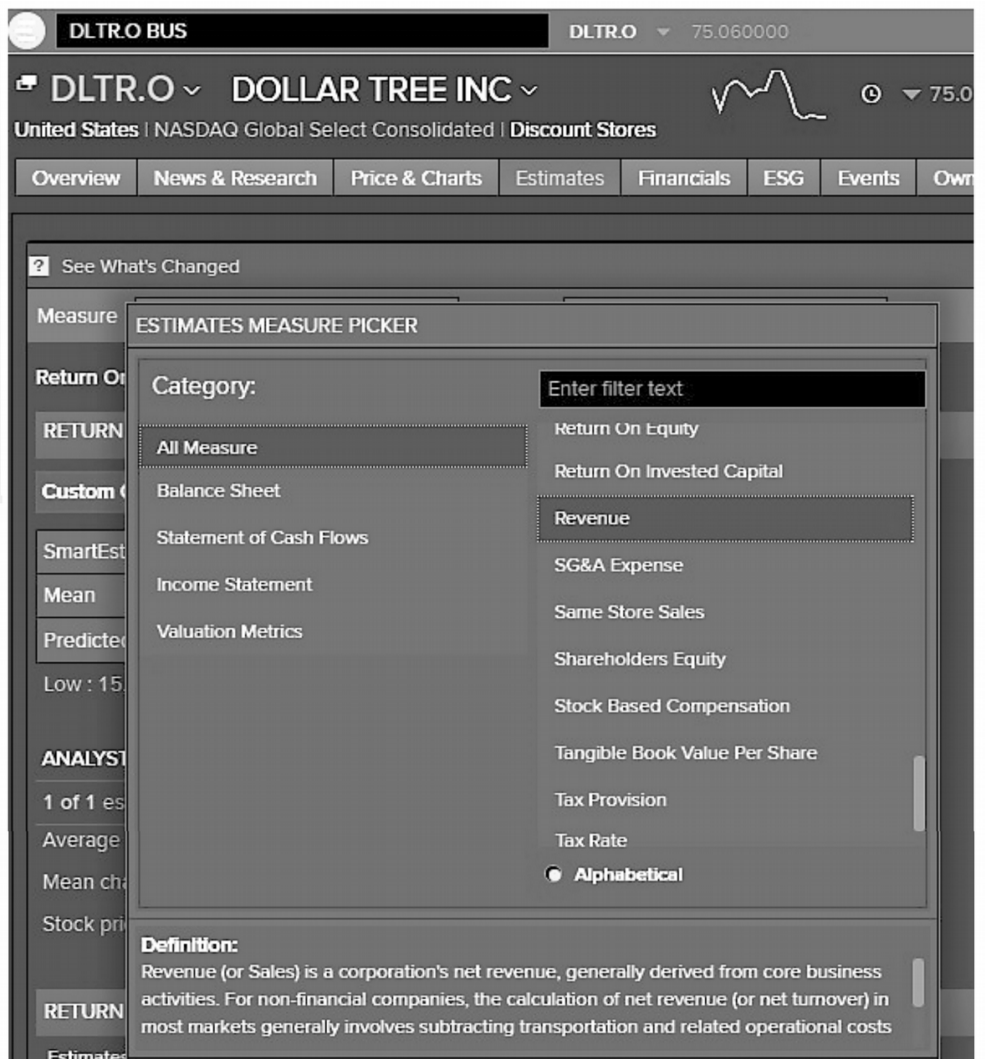

Source:Thomson Reuters Information system 


\section{Figure 4}

\section{Sales volume for the selected period (screenshot)}

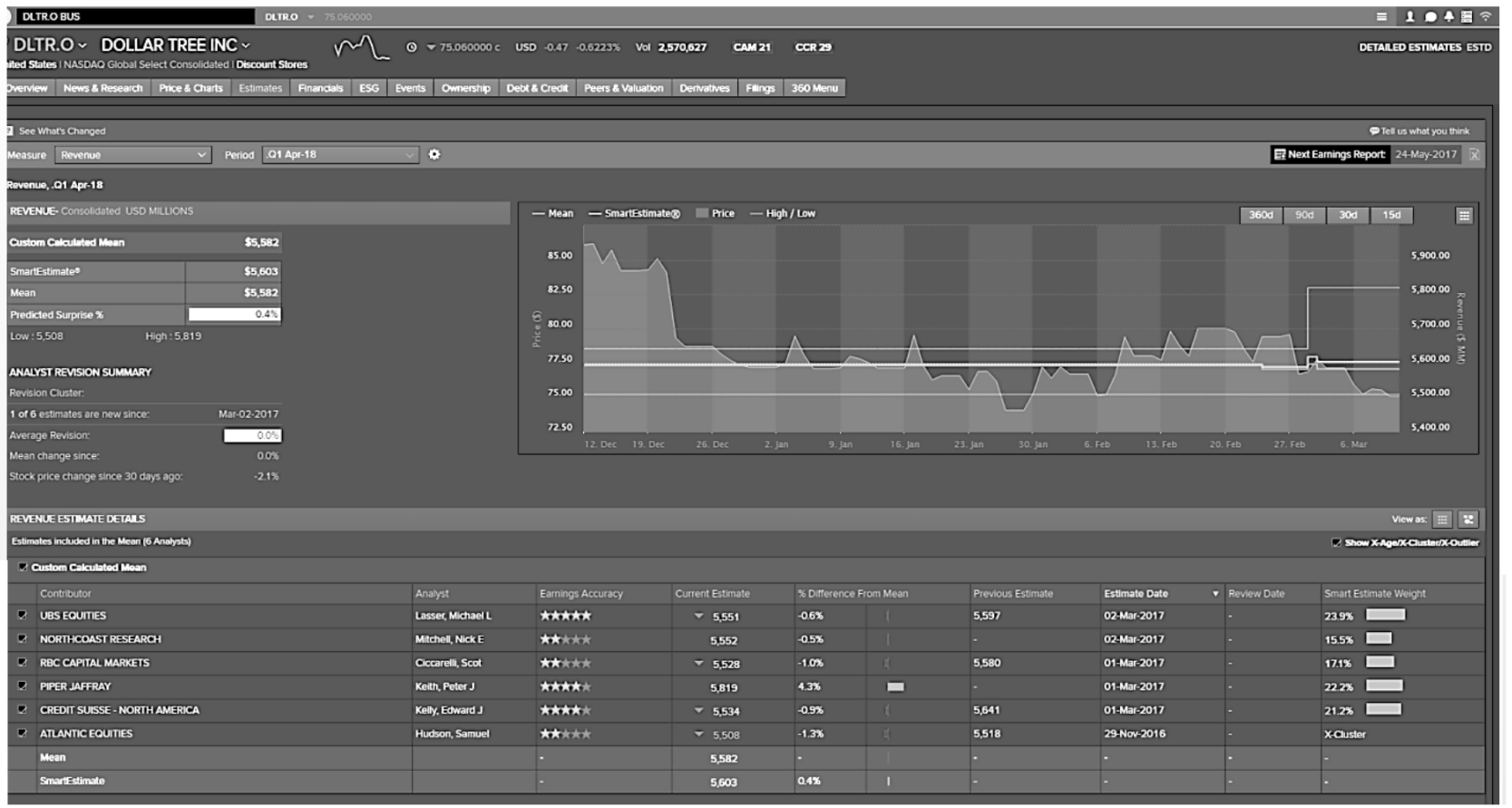

Source:Thomson Reuters Information system

\section{Figure 5}

The application of the valuation option (screenshot)

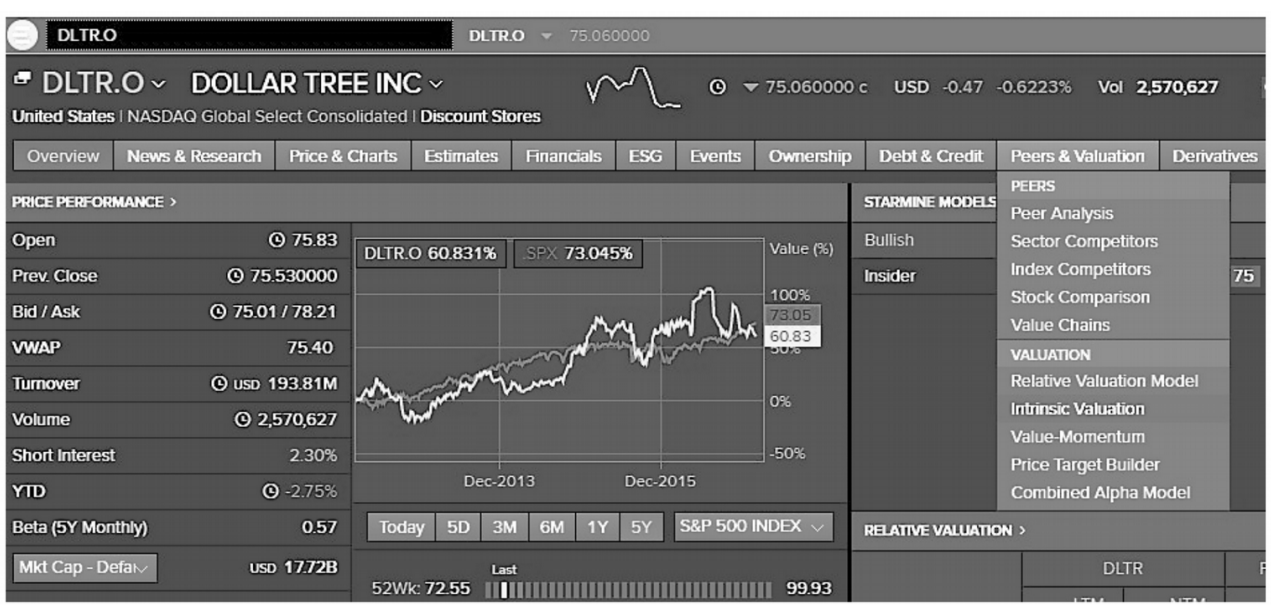

Source:Thomson Reuters Information system

Please cite this article as: Bogatyrev S.Yu. Analytical Capabilities of Modern Information Systems as Part of the Income-Based Business Valuation Method. Digest Finance, 2018, vol. 23, iss. 1, pp. 41-54. 


\section{Figure 6}

The application of the valuation option to Dollar Tree, Inc. (screenshot)

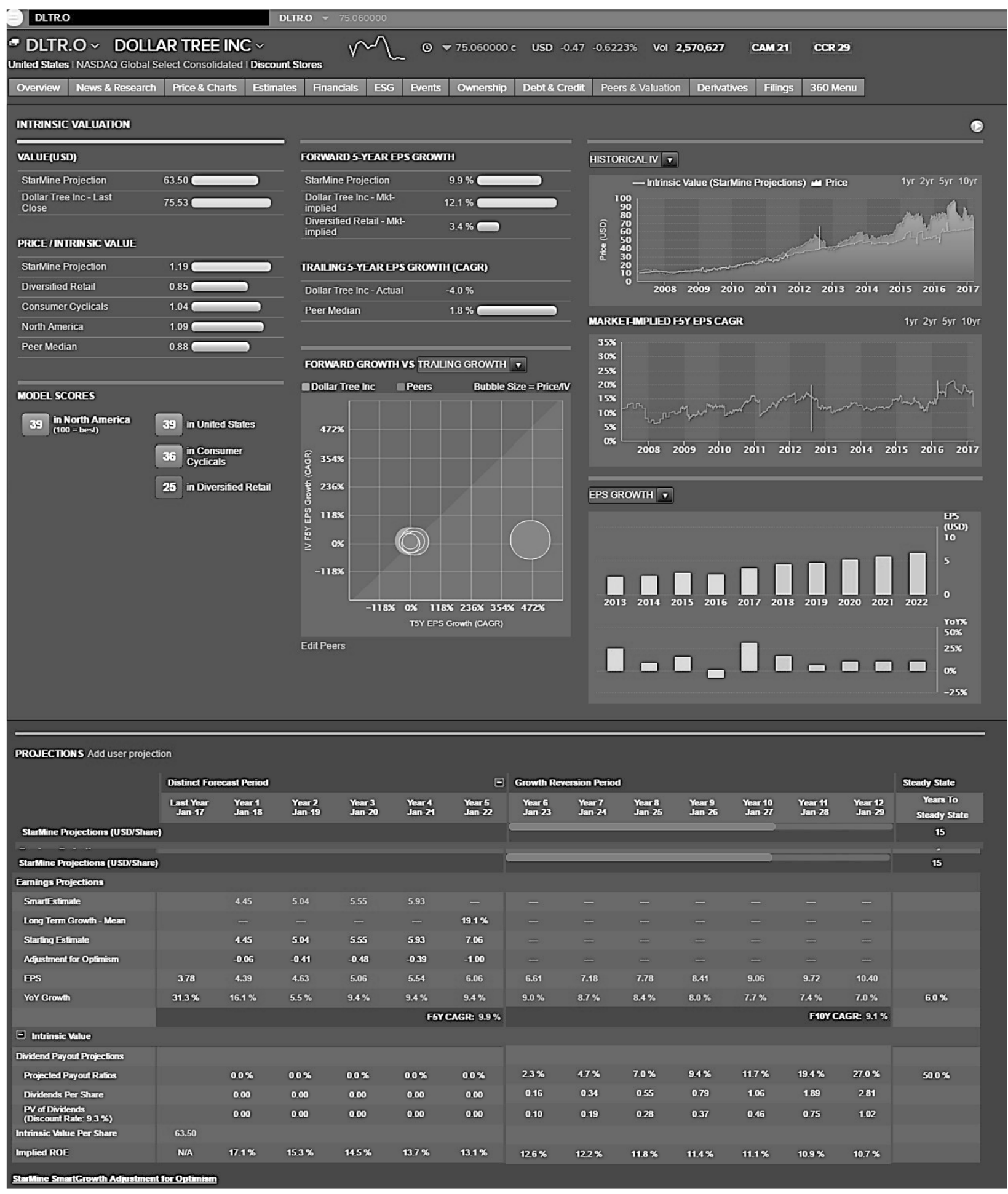

Source:Thomson Reuters Information system

Please cite this article as: Bogatyrev S.Yu. Analytical Capabilities of Modern Information Systems as Part of the Income-Based Business Valuation Method. Digest Finance, 2018, vol. 23, iss. 1, pp. 41-54. https://doi.org/10.24891/df.23.1.41 


\section{Figure 7}

Forecasts (screenshot)

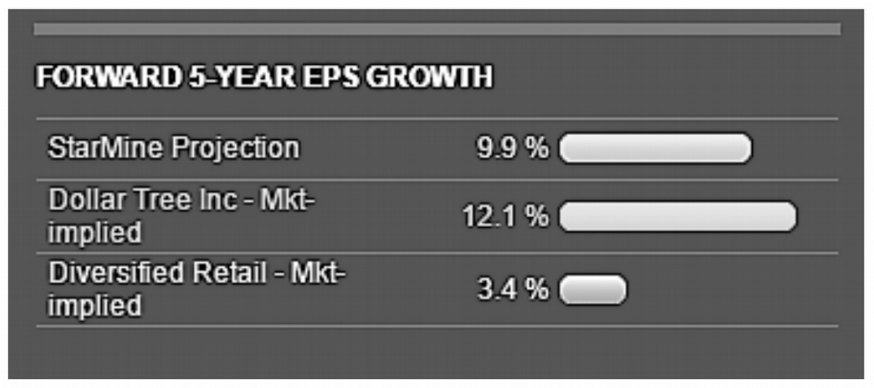

Source: Thomson Reuters Information system

\section{References}

1. Gray R.P., Kester R.B., Minor B.H. Working Capital Considerations for Business Valuations. Financial Valuation and Litigation Expert, 2017, iss. 68, pp. 16-19.

2. Bingham B.B. Valuation Professionals: Be Aware of New Rules; Speak Your Mind. Financial Valuation and Litigation Expert, 2013, iss. 45, pp. 21-22.

URL: http://www.valuationproducts.com/files/Valuation_of_Special_Use_Properties.pdf

3. Hitchner J. 'LinkedOut'. A Response to a Business Valuation Standards Discussion. Financial Valuation and Litigation Expert, December 2012/January 2013, iss. 40, pp. 1-6.

URL: http://www.valuationproducts.com/files/Issue-40_LInked-Out.pdf

4. Burkert R.P., Dohmeyer B. Mean Reversion Model to Adjust Excess Compensation. Financial Valuation and Litigation Expert, December 2012/January 2013, iss. 40, pp. 9-12.

URL: http://www.valuationproducts.com/files/Issue-40-Burkert-Article.pdf

5. Chaffee D.B.H. Option Pricing as a Proxy for Discount for Lack of Marketability in Private Company Valuations. Business Valuation Review, 1993, vol. 12, iss. 4, pp. 182-188. URL: https://doi.org/10.5791/0882-2875-12.4.182

6. Longstaff F.A. How Much Can Marketability Affect Security Values? The Journal of Finance, 1995, vol. 50, iss. 5, pp. 1767-1774. URL: https://doi.org/10.1111/j.1540-6261.1995.tb05197.x

7. Finnerty J.D. The Impact of Transfer Restrictions on Stock Prices. Financial Management Association International, 2008 FMA European Conference (revised November 2007 and corrected October 2009). Fordham University, 2003. pp. 15-21.

8. Ji-Fan Ren S., Wamba S.F., Akter Sh. et al. Modelling Quality Dynamics, Business Value and Firm Performance in a Big Data Analytics Environment. International Journal of Production Research, 2017, vol. 55, iss. 17, pp. 5011-5026. URL: https://doi.org/10.1080/00207543.2016.1154209

9. Greene D. Valuations in Corporate Takeovers and Financial Constraints on Private Targets. Journal of Financial \& Quantitative Analysis, 2017, vol. 52, iss. 4, pp. 1343-1373. URL: https://doi.org/10.1017/S0022109017000527

10. Reilly R.F. DLOM in Valuation of Closely Held Company Securities in Family Law. American Journal of Family Law, 2017, vol. 31, iss. 1, pp. 34-50.

11. Reilly R.F. The Asset-Based Approach to Business Valuation in Family Law (Part I of III). American Journal of Family Law, 2017, vol. 31, iss. 2, pp. 69-80.

Please cite this article as: Bogatyrev S.Yu. Analytical Capabilities of Modern Information Systems as Part of the Income-Based Business Valuation Method. Digest Finance, 2018, vol. 23, iss. 1, pp. 41-54. 
12. Kung-Cheng Ho, Shih-Cheng Lee, Chien-Ting Lin et al. A Comparative Analysis of Accounting-Based Valuation Models. Journal of Accounting, Auditing \& Finance, 2017, vol. 32, iss. 4, pp. 561-575. URL: https://doi.org/10.1177/0148558X15623043

13. Ali A., Hwang L.-S., Trombley M.A. Residual-Income-Based Valuation Predicts Future Stock Returns: Evidence on Mispricing vs. Risk Explanations. The Accounting Review, 2003, vol. 78, no. 2, pp. 377-396. URL: https://doi.org/10.2308/accr.2003.78.2.377

14. Pae Jinhan, Yoon Sung-Soo. Determinants of Analysts' Cash Flow Forecast Accuracy. Journal of Accounting, Auditing \& Finance, 2012, vol. 27, iss. 1, pp. 123-144. URL: https://doi.org/10.1177/0148558X11409148

15. McIntosh W. Forecasting Cash Flows: Evidence from the Financial Literature. The Appraisal Journal, 1990, vol. 58, April, pp. 221-229.

16. Lorek K.S., Willinger G.L. Multi-Step-Ahead Quarterly Cash-Flow Prediction Models. Accounting Horizons, 2011, vol. 25 , iss. 1 , pp. $71-86$.

17. Francis J.M. Deriving IRR Sets from Market Transactions. The Appraisal Journal, 1995, vol. 63, iss. 2. URL: http://www.freepatentsonline.com/article/Appraisal-Journal/17015352.html

18. Hamilton C. Is It the Market Approach or the Income Approach? Financial Valuation and Litigation Expert, 2011, iss. 33, p. 15. URL: http://www.valuationproducts.com/files/Issue_33_Hamilton.pdf

19. Bogatyrev S.Yu. Testing Behavioral Asset Pricing Models on Russian Financial Market. International Journal of Trade, Economics and Finance, 2014, vol. 5, iss. 1, pp. 48-51. URL: https://doi.org/10.7763/IJTEF.2014.V5.339

20. Hitchner J. How to 'Rig' a Valuation: The Discount Rate. Financial Valuation and Litigation Expert, 2013, iss. 41, pp. 1-6.

\section{Conflict-of-interest notification}

I, the author of this article, bindingly and explicitly declare of the partial and total lack of actual or potential conflict of interest with any other third party whatsoever, which may arise as a result of the publication of this article. This statement relates to the study, data collection and interpretation, writing and preparation of the article, and the decision to submit the manuscript for publication. 